\title{
Programa pictórico de la Iglesia de la Inmaculada del antiguo colegio de Clérigos Menores, de Málaga
}

\author{
Sebastián González Segarra *
}

RESUMEN ABSTRACT

Los conjuntos de pintura decorativa existentes en Málaga son escasos, y en su mayoría parecen haber sido realizados en la primera mitad del siglo XVIII.

Uno de los más interesantes y espectaculares es el que decora

la Iglesia de la Inmaculada, del que fue antiguo colegio de Clérigos Regulares Menores. En su programa se unen contenidos marianos con aquellos que exaltan la Congregación.
The decorative collection pictures that exist in Malaga are few and they seem to have been done in the fist half of the one that decorates.

One of the most interesting and spectacular is the one that decorates The Inmaculada church, wich was once the old of "Chierici Regolari Minori" (PP. CaraccioliniAdorno Fathers) Scholl. In its programme it joins marian themes with those that exalt the Congregation itself.

En la Iglesia de la Inmaculada Concepción, de Málaga, antigua iglesia de Clérigos Menores, encontramos representaciones de diversos temas, que decoran bóvedas y pechinas de su cubierta, integrando un programa relacionado con la Orden y con la advocación a la que está dedicada el templo.

La Orden, fue fundada, en Nápoles, por Juan Agustín Adorno, Francisco (Ascanio) Caracciolo y Agustín (Fabricio) Caracciolo, con el apoyo de Sixto $\checkmark$. Fue precisamente en Valencia donde San Luis Beltrán predijo al noble

\footnotetext{
Doctor en Historia del Arte. UNED.
} 
genovés Adorno que sería fundador de una orden religiosa ${ }^{1}$. Tras la presentación de las reglas ante Sixto V, por Adorno y Francisco Caracciolo, se les permite, por el breve del 1 de julio de 1588 hacer votos solemnes, elegir general y redactar Constituciones. La Orden es aprobada por Gregorio XIV en 1591 y posteriormente por Clemente VIII y Pablo V.

Los fundadores, pretendían crear una orden de sacerdotes ejemplares y celosos ${ }^{2}$ dedicados al apostolado, con un tipo de vida mixta, contemplativa y activa. Añadían el voto de no aspirar a tener dignidades eclesiásticas fuera de la orden, además de pobreza, castidad y obediencia. La vida de la Congregación, según sus Constituciones, se orienta hacia la predicación, confesión, obras de caridad en hospitales y cárceles y administración de sacramentos. Cuentan, además, como prácticas especiales: la oración circular, la penitencia circular, y la adoración ante el Santísimo. Sus patronos son la Inmaculada, San Miguel y San José, su insignia o escudo de armas la Resurrección de Cristo y su lema "AD MAIOREN RESURGENTIS GLORIAM», que debe su origen a que los fundadores hicieron su profesión el domingo de Pascua de Resurrección de 1589.

Aunque el verdadero fundador de la orden fue Adorno, tiene una mayor proyección la figura de Francisco Caracciolo, beatificado por Clemente XIV el 4 de Junio de 1769 y canonizado por Pío VI el 24 de Mayo de 1807. Es considerado el verdadero fundador y primer promotor del culto a la Eucaristía, con la adoración perpetua a la exposición solemne.

La expansión de la orden hacia España se encontró con dificultades, creándose dos conventos en Madrid (Porta Coeli en 1594 y Espíritu Santo en 1599), y otros en Alcalá de Henares (San José, 1604), Barcelona (Espíritu Santo, 1685), Calatayud (Santa María de la Peña, 1631), Granada (San Gregorio, 1686) Salamanca (San Carlos, 1612), Sevilla (Espíritu Santo, 1625), San Pedro de Alcántara (1680), Valladolid (Anunciación, 1601) y Valencia (San Pío, 1698).

Como señala Jiménez Priego ${ }^{3}$, la escasa difusión de la orden, la temprana muerte de los fundadores, la reducida influencia social que alcanza

Una exposición detallada del proceso de formación de la orden, basada fundamentalmente en la obra del P. Eusebio Quintana, se puede encontrar en JimÉnez Priego, María Teresa. "Segunda serie programática de Pedro Rodríguez Miranda", Espacio, tiempo, forma, serie VII, n. ${ }^{\circ}$ 4, Madrid, 1991, págs. 195-238.

2 Sobre este aspecto de la orden y su relación con la pintura en los aposentos de los clérigos una circular del Provincial José Beato, del 25 de junio de 1825, manifestaba la obligación, por parte de éstos, de desterrar "...el lujo y singularidad en los hábitos y demás vestidos, en los adornos, y pinturas de los aposentos". A.H.C.C.MA. PP. CC. MM. Libro de Capítulos y Consultas, legajo $881, n .{ }^{\circ} 3$, fol. 19 .

Jiménez Priego, María Teresa, Op. cit., Madrid, 1991, pág. 214. 
Programa pictórico de la Iglesia de la Inmaculada del antiguo colegio de Clérigos...

la orden explican la breve dimensión concedida a los fundadores en los tratados hagiográficos, la tardía beatificación y canonización de Francisco Caracciolo y las escasas creaciones iconográficas relacionadas con la orden y con sus más insignes figuras.

En Málaga, es la iglesia (Fig. 1) lo único que queda del antiguo convento y colegio. La fundación en nuestra ciudad se encuentra relacionada con el ingreso en la orden del malagueño Don Alfonso de la Cruz Bastardo ${ }^{4}$, que entra en la congregación tras la muerte de su joven esposa. Su hijo único y heredero D. Diego, que había ingresado en el noviciado de Madrid, entregó su herencia a la Religión, con la obligación de fundar un colegio en la ciudad. Para la ejecución del testamento, Alfonso de la Cruz, ordenado sacerdote, llegó a Málaga junto a dos compañeros en el año 1631, instalándose en unas habitaciones, cerca del Monasterio de monjas de San Agustín. Allí permanecieron hasta

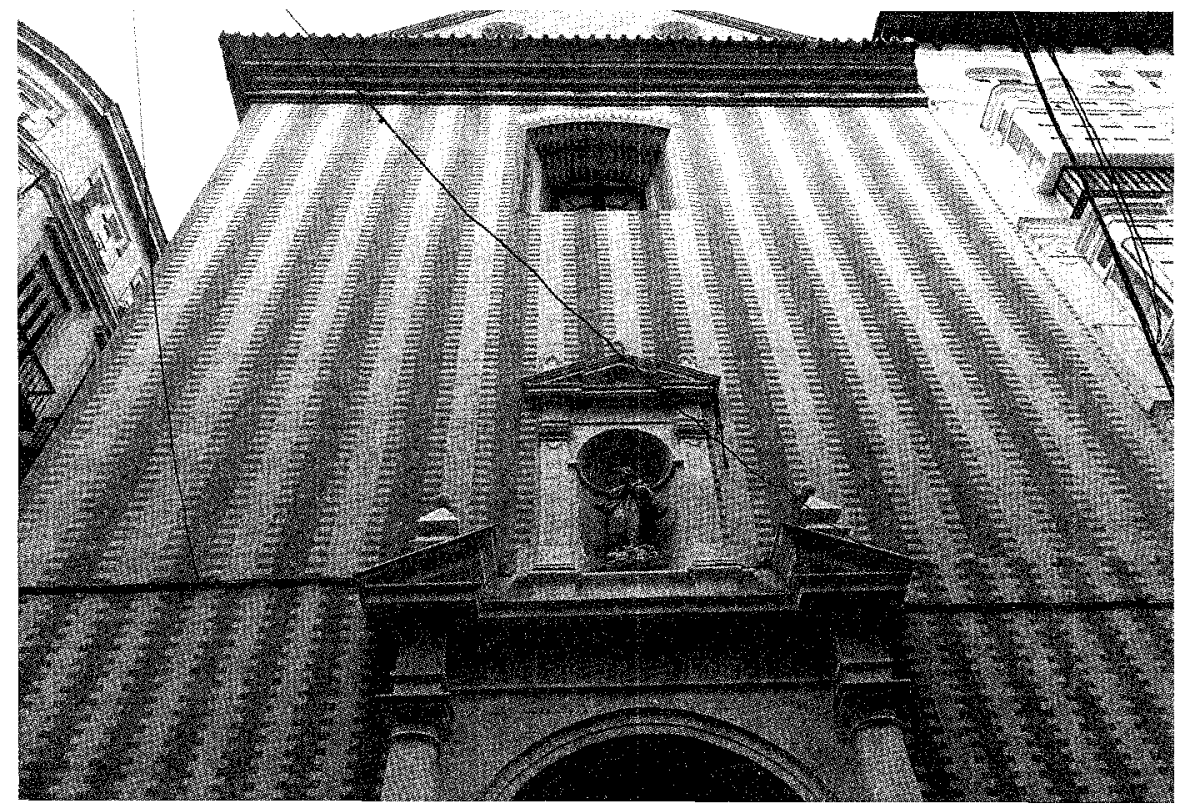

Fig. 1. Iglesia de la Inmaculada Concepción. Fachada principal.

4 PISELLI, Clemente. Notizia Historici della religione de PP. Chierichi Rigolari Minori, Stamperia di Gio Francesco Buagni, MDCCX, Roma, 1990, págs. 380-383. 
que, en el año 1637 la ciudad solicitó la licencia para la fundación, retrasada, por las epidemias y oposición de clero y otras órdenes. El monarca autorizó su instalación, como hospicio, en las afueras de la ciudad, cerca de Puerta Oscura, en el año 1648. Posteriormente se trasladan junto a la Puerta de Espartería (1665) y junto a la Ermita de la Concepción, ayuda de la Parroquia de San Juan, donde abrieron escuelas para leer Artes, Teología Escolástica y Moral, siguiendo las dificultades para la aprobación definitiva de su instalación, que tuvo lugar el año 1673, año en que se dio posesión de la ermita y casas adyacentes.

Hasta 1701 se mantuvieron en la ermita, iniciándose ese año las obras de la iglesia y colegio, terminadas, respectivamente, en los años 1710 y 1721 , dedicándose el templo el día 3 de enero de $1710^{5}$.

La iglesia fue edificada por dicha orden como consecuencia de la donación realizada por D. Jerónimo Fernández de Mendoza y Salazar el 4 de Junio de 1701, por la que entregaba una casa inmediata al Colegio, que servía de iglesia habitación a sus religiosos, con la condición de edificarla en dicho sitio ${ }^{6}$.

El edificio, de planta de cajón con una tribuna a los pies y un tramo más amplio cubierto con bóveda elíptica ante el altar ${ }^{7}$, cuenta con pinturas al fresco en las pechinas, muy ennegrecidas, que representan a los tres Arcángeles y al Ángel de la Guarda, presentados, como normalmente se hace con los evangelistas. Estas imágenes son atribuidas por Agustín Clavijo a Diego de la Cerda. Asimismo, se aprecia el estilo del autor en la cabecera, en la Coronación de la Virgen.

El programa está integrado por tres obras rectangulares situadas longitudinalmente, desde los pies a la cabecera de la iglesia, en cada uno de los tramos de la nave. En las pechinas de la cúpula (Fig. 2), completan el grupo las representaciones de los arcángeles.

A los pies de la iglesia, sobre el tramo en el que se sitúa el coro, se encuentra la Fundación de la Orden de Clérigos Menores o quizás mejor Aprobación de las reglas de la Orden de Clérigos Menores por Sixto V. (Fig. 3)

5 Medina Conde, Cristóbal. Conversaciones históricas malagueñas. Materiales de noticias seguras para formas la historia civil, natural y eclesiástica de la M.I. ciudad de Málaga vol. III Málaga, 1793, págs. 185-190.

6 Archivo Histórico Provincial de Málaga (A.H.P.M.A.). Escribanía de Enríquez de Medrano legajo 2106, años 1701-1704, fols. 644-663.

7 Temboury describe así su estado en sus notas manuales. Archivo Temboury (A.T.) Carpeta 67. Edificios e instituciones religiosas. Iglesia Convento de la Concepción (Clérigos Menores). 


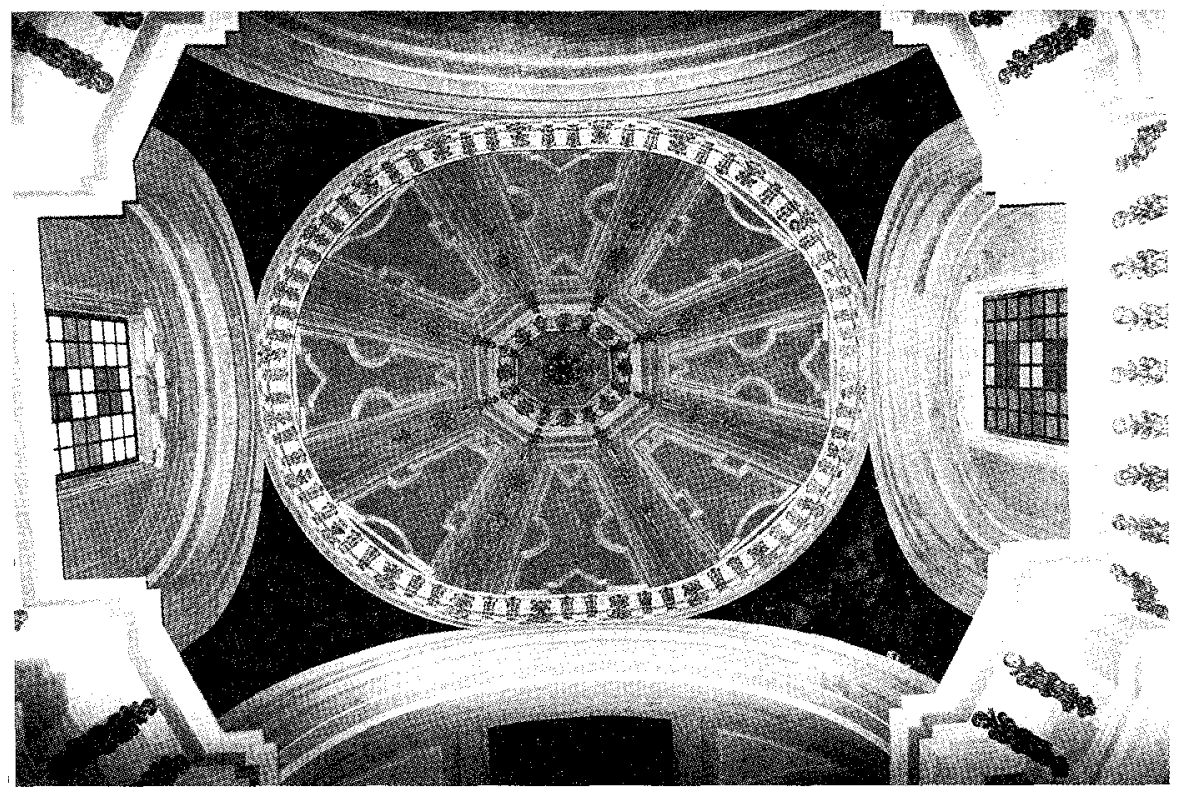

Fig. 2. Iglesia de la Inmaculada Concepción. Cúpula

En la escena, se representa el momento en que Adorno y Caracciolo reciben la aprobación papal de Sixto $\mathrm{V}$. En la presentación de sus personajes principales se recurre a una ordenación bastante clásica, que podemos encontrar en tempranas obras de Giotto (San Francisco presentando al Papa la regla de su Orden, de Santa Croce, en Florencia) o Guirlandajo (El Papa aprobando la Orden de San Francisco, de Santa Trinita, en Florencia).

Su técnica, el fresco, puede considerarse casi excepcional en la ciudad pues sólo se cuenta con los antecedentes de Cesar de Arbasía y Alonso Cortés ${ }^{8}$, coincidiendo, en este principio de siglo, la realización de tres conjuntos de decoraciones al fresco: el citado; el que decora la bóveda de la cripta de la iglesia del Hospital de San Lázaro; y el de la bóveda de la capilla del Sagrario en la Iglesia de San Pedro de los Percheles.

Según Clavijo, "recuerda en gran manera la pintura que existía en la Iglesia de los Santos Mártires hasta el año 1931 en que fue destruida,

\footnotetext{
8 Al primero corresponden los frescos de la Pasión, de la Catedral de Málaga, realizados a fines del s. Xv y al segundo los de la cúpula de la Iglesia del Santo Cristo de la Salud, realizados ya bien entrado el siglo $x$ VIII.
} 


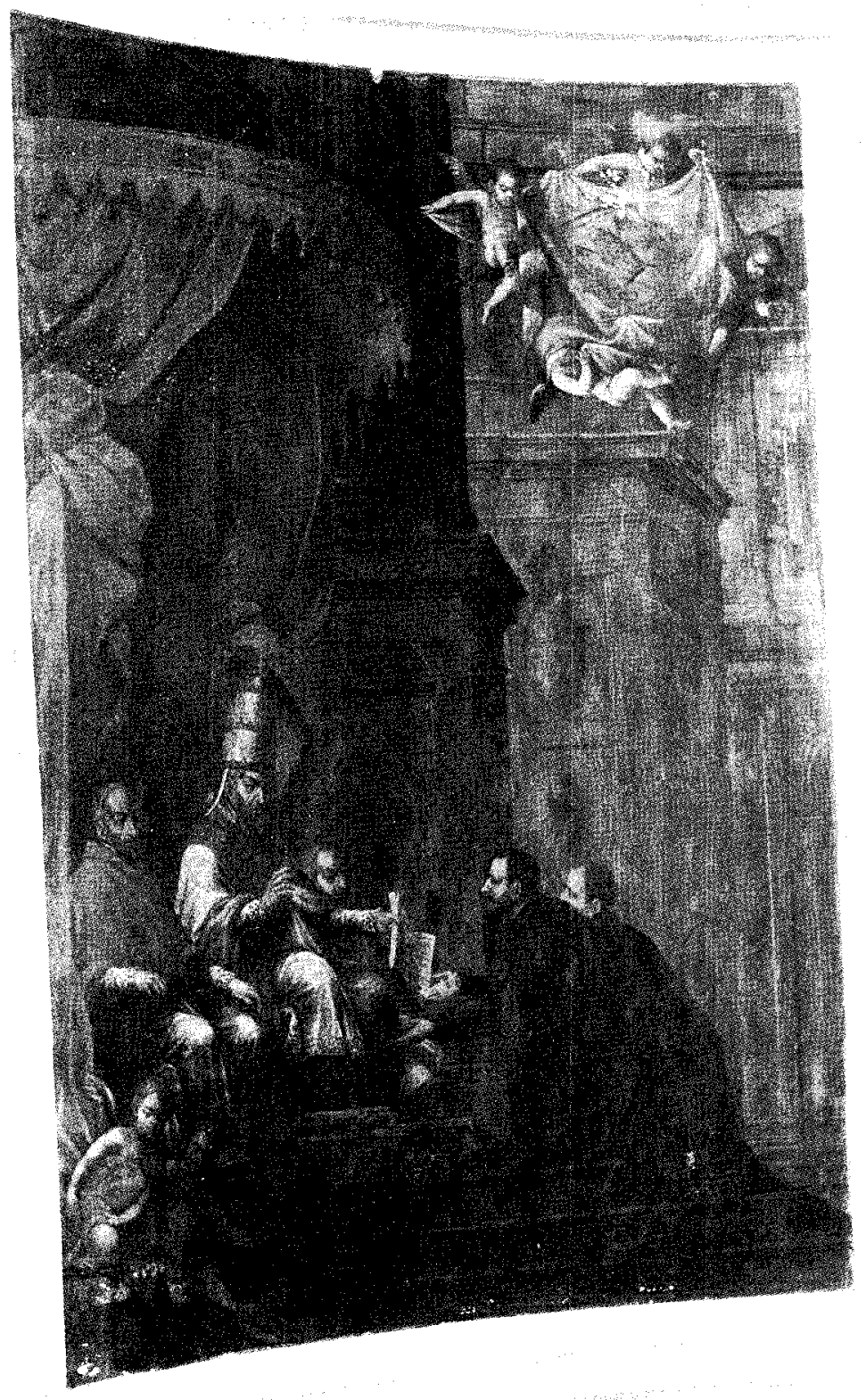

Fig. 3. Aprobación de la Orden de Clérigos Menores. Iglesia de la Concepción. 
Programa pictórico de la Iglesia de la Inmaculada del antiguo colegio de Clérigos...

obra de Niño de Guevara "Fundación de la Venerable Orden Tercera" Fig. 4-, aunque la fuente común de ambas parta posiblemente de alguna estampa grabada de Italia (recuérdese entre otras obras, la de Andrea Vaccaro existente en el Palacio Real de Madrid, que representa la "Aprobación por el Papa de la Orden de Teatinos"» 9.

Esta estampa inspiradora pudo ser alguna, como la grabada, posiblemente, por Francesco Salviati, en la que se represente La Beneficencia, o, más probablemente, aquélla en la que Agustino Ciampellio representa la aprobación de las reglas de la Compañía de Jesús, que Jiménez Priego considera también, posiblemente inspiradora, en algo, de la obra de Pedro Rodríguez de Miranda existente en el Museo del Prado ${ }^{10}$, pudiendo serlo igualmente de otra serie de cuadros que muestran concepciones compositivas muy semejantes, como el de Valdés Leal, que representa a San Ignacio recibiendo la Bula de fundación, existente en el Museo de Bellas Artes de Sevilla ${ }^{11}$, o la obra, del mismo autor, que muestra a San Ignacio recibiendo del Papa Paulo IV las aprobación de las Constituciones, de la Iglesia de San Pedro, en Lima; dos de Carducho, existentes en el Museo del Prado (Visión del Papa Víctor II y San Bruno y seis compañeros se presentan por primera vez a San Hugo, obispo de Grenoble); o una obra anónima del siglo XVIII, también del Museo, que representa a San Pío V dando la regla a unos religiosos benedictinos.

La estampa de Campelio, es más simple que la obra malagueña, pero las similitudes son evidentes, mayores aún que con la madrileña, y semejante a la de Lima, si bien la monumentalidad del fondo arquitectónico es mucho mayor y recurre a un arco de medio punto que arranca de una cornisa que recorre el muro, pero tiene un mayor desarrollo vertical y es presentada en un ligero contrapicado que acentúa la importancia compositiva del dosel y de los ángeles, que equilibran este espacio de la obra. Por contra las figuras del fundador y de Sixto $V$ tienen una mayor semejanza con el modelo, siendo también escasos los acompañantes, dos prelados y Adorno, que curiosamente se sitúa en un segundo plano, contrariamente a como se represente por Miranda en la misma escena.

9 Clavijo García, Agustín. La pintura barroca en Málaga, tesis doctoral publicada en microfichas, Universidad de Málaga, Barcelona, pág. 1.025.

10 Jiménez Pfiego, María Teresa. Op. cit., Madrid, 1991, pág. 227-228.

11 Como indica Valdivieso, esta composición parece estar inspirada, a su vez, en el grabado de Carlos van Mallery, que ilustra la vida de San Ignacio, del padre Ribadeneira. VALDEVIESO, Enrique. Valdés Leal, Sevilla, 1988, pág. 115. 


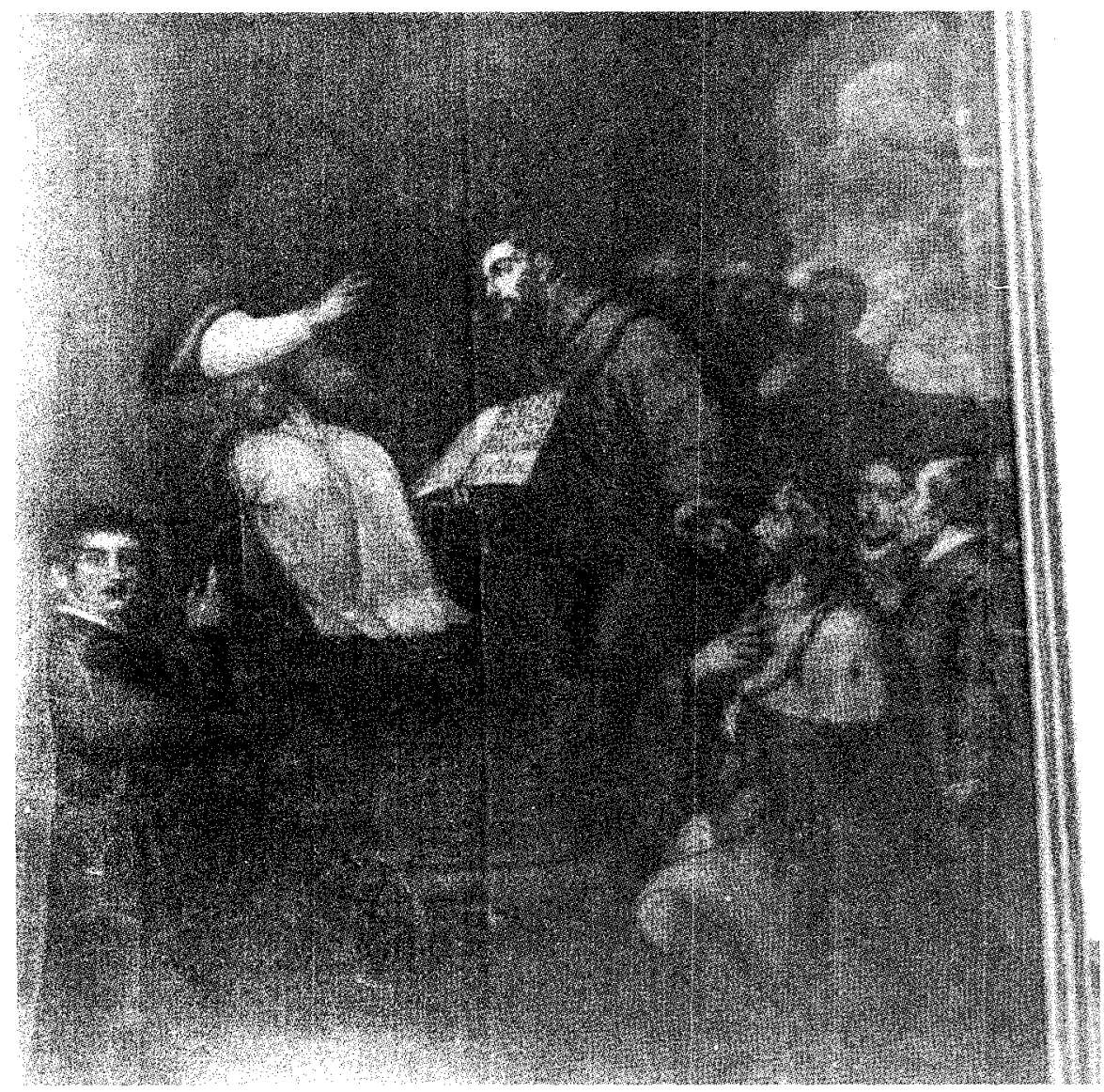

Fig. 4. Fundación de la Orden Tercera franciscana. Niño de Guevara. Parroquia de los Santos Mártires (desaparecido)

Se muestra una escena no excesivamente compleja, ubicada en el interior de un fastuoso templo clásico del cual casi sólo se perciben suelo y articulación mural en la zona derecha del cuadro. Se ha representado en diversos planos para dar sensación de profiundidad natural. Sobre los colosales pedestales aparecen figuras completas de apóstoles enmarcados en óvalos.

A la izquierda, casi todo el espacio es ocupado por un gran dosel circular que fue rojo intenso y por el proceso de torcido del color ha pasado a un violáceo-terroso-dorado, bajo el cual el Sumo Pontífice, sentado y con un consejero a la espalda, entrega lo que parece ser un pergamino a 
los fundadores. Éstos, arrodillados sobre un podium, la reciben de manos de una figura infantil que la pasa de éste a aquéllos. En la parte inferior, a la izquierda, dos figuras infantiles y angélicas completan la escena portando sendas mitras pontificales, mientras en la parte superior derecha revolotean cuatro más en diversas posturas y actitudes, transportando un elegante y distinguido paño blanco que lleva en su centro el escudo dorado del vaticano: tiara cruzada en diagonal por dos grandes llaves.

Sin que existan pruebas documentales que permitan su adjudicación a la mano de Diego de la Cerda, el profesor Clavijo sí aprecia en la obra caracteres que pueden justificar su atribución. Estos serían, fundamentalmente, los rasgos anatómicos de la cabeza de Sixto $V$, con ojos grandes y sombreados, cejas curvadas y destacadas, y nariz recta y alargada, Serían los mismos que más tarde se podrán encontrar en el San Gregorio Magno de la iglesia del Hospital de Santo Tomé. También lo serían los detalles escultóricos que adornan los pedestales que vuelven a repetirse en la pintura de San José con el Niño del mismo hospital ${ }^{12}$.

No cuenta, pues, la obra, con la espectacularidad que suele caracterizar a otras, que representan estos temas. El reducido número de personajes, la naturalidad de las posturas y del enmarcado espacial, la alejan de estos modelos barrocos y, por el contrario, la acercan a los esquemas compositivos y soluciones ambientales, formales, e incluso cromáticas que encontramos en algunas de las escenas de la serie de la Vida de la Virgen en S. Pedro de los Percheles, obra al parecer de este mismo periodo.

El Cristo Resucitado, de caracteres y dimensiones semejantes a la obra anterior (Fig. 5), emblema de la congregación, se sitúa en el tramo siguiente, anterior a la cúpula. En esta pintura parece prevalecer la concepción tradicional del tema, a pesar de ser errónea y contraria a las indicaciones de Trento e Interián ${ }^{13}$ : ascendiendo sobre su tumba abierta, con el sudario blanco extendido por los suelos, y recogido por pequeños ángeles.

Como en la obra de Tintoretto, pintado tras Trento, en el Palacio de los Dogos, Jesús, con su cuerpo resplandeciente, como lo describe Jerónimo Nadal ${ }^{14}$, se eleva de la tumba abierta, en este caso por unos angelitos, con su manto rojo, símbolo de que ya ha sufrido la pasión, y blanco estandarte

12 Clavijo, Agustín. Op. cit., Barcelona, 1993, pág. 1.060.

13 INTERIÁN DE AYALA, Juan. El pintor christiano, y erudito, o tratado de los errores que suelen cometerse frequentemente en pintar, y esculpir las imágenes sagradas, Madrid, 1782, vol. I, págs. 464-474.

14 NADAL, Jerónimo. Evangeliae historiae imagines, lam. 134. 


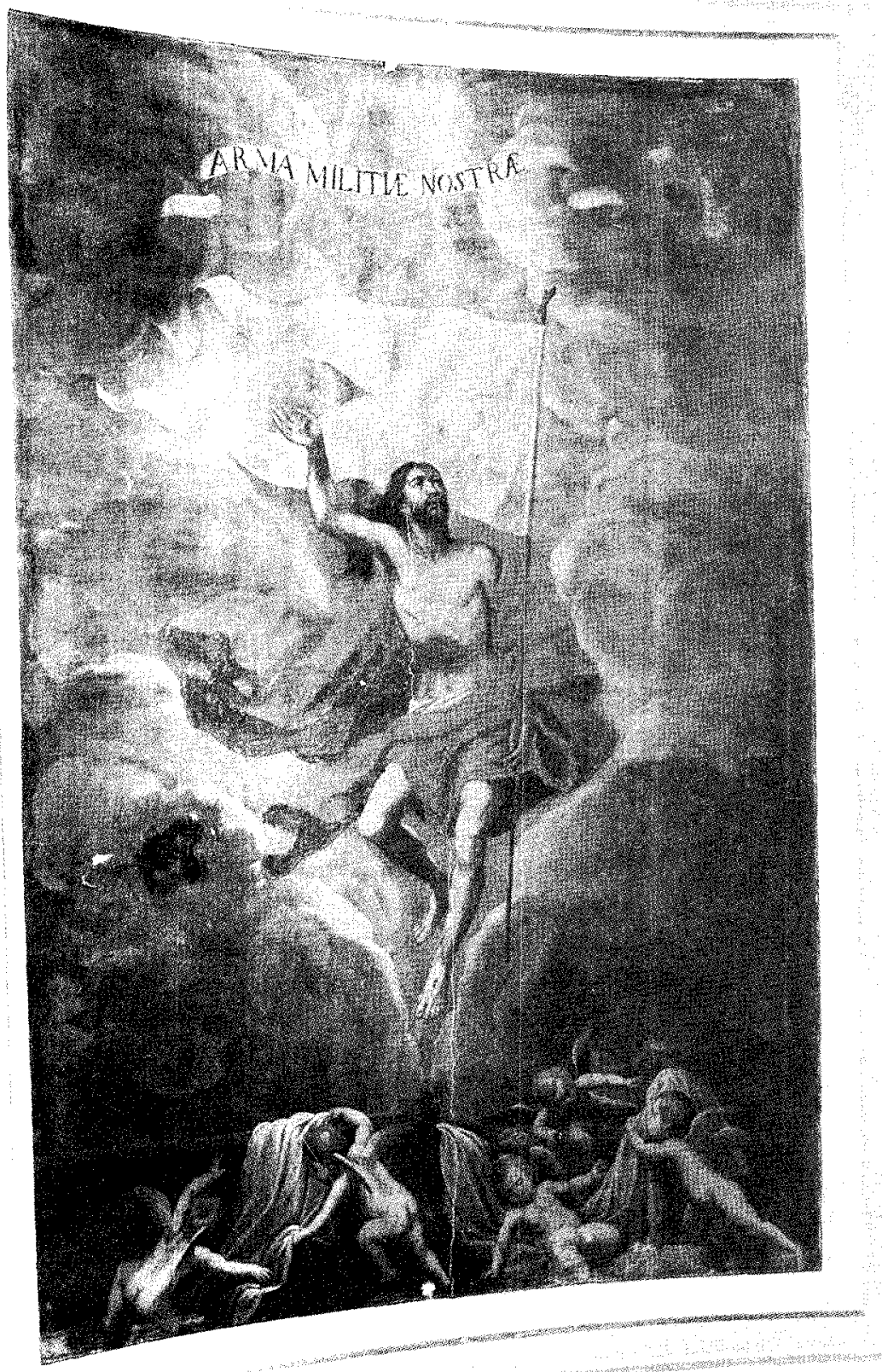

Fig. 5. Resucitado. Iglesia de la Concepción. 
en mano ${ }^{15}$, que alude a su triunfo sobre la muerte, con el entusiasmo de la victoria. Sobre él, en una estrecha banda, se puede leer el lema "ARMA MILITIAE NOSTRA", que refleja una de las máximas religiosas de la nueva Orden de Clérigos Menores. Le da más trascendencia, pues, al triunfo sobre la muerte que a su naturaleza no humana.

La imagen puede remitir a los Apócrifos (Agrapha 2. Variantes de los manuscritos evangélicos 11) donde se dice:

"Y de repente sobre la hora tercia, las tinieblas se extendieron por toda la faz de la Tierra y descendieron ángeles del cielo. Y al resucitar con el resplandor de Dios vivo se elevaron junto a El, y al momento sobrevino la luz",

Excepto en lo referido a la forma de aparecer el sepulcro, la representación respeta las indicaciones de Pacheco al aparecer «con manto roxo $y$ paño blanco, descubiertas y gloriosas sus llagas, con grandes resplandores de luz y no escusemos su acompañamiento de ángeles y serafines, como lo puso el P. Gerónimo Nadal..." ${ }^{16}$. Igualmente, como señala el erudito Ayala, mantiene su diestra en alto "en significativo ademán de indicar que el reino de los Cielos será su eterna morada" 17.

En la parte inferior de la escena, aparece el sepulcro rodeado de seis angelitos alados en diversas posturas y actitudes, preocupados en recoger la sábana en que fuera envuelto el cuerpo de Cristo. En la superior, observamos un rompimiento de gloria de variadas nubes y luz bien distribuidos, especialmente intensificado en torno a la figura del Resucitado.

La figura triunfante de Cristo, aparece en actitud ascensional grave y solemne, claramente estilizada y con un gran manto rojo que, en amplio movimiento, crea líneas diagonales y horizontales. Unidas a las del estandarte, equilibran, frenan podríamos decir, el sentido ascensional de la escena que a su vez subraya la mirada fija de Jesús en lo alto. La figura es de correcto y estilizado dibujo anatómico e intenso modelado escultórico, originado por la fuerte luz que le viene de lo alto. En ella, destacan el estudio de los pies y cabeza, de apreciable y serena belleza. Por el contrario, las nubes crean, en las zonas más oscuras, sensación de pesadez, por

\footnotetext{
15 Como recomendaba Pacheco, excepto en lo relativo a la tapa del sepulcro, las llagas, que no aparecen o al menos no se aprecia, y el paño blanco. PAcheco, Francisco. El Arte de la Pintura, edición de Bonaventura BASSEGODA Y HugAs, Madrid, 1990, págs. 648-650.

16 Ibidem., pág. 650.

17 Interián de Ayala, Juan. Op. cit., tomo I, c. XX. pág. 465.
} 
su carácter excesivamente denso, y los angelitos aparecen excesivamente forzados en sus actitudes corpóreas.

La obra es evocadora, en su sentido triunfante, de la obra de Murillo, que se encuentra en la Academia de Bellas Artes de Sevilla, recordando asimismo la obra del mismo autor del Convento de la Merced Calzada de Sevilla, hoy en el Museo de Bellas Artes de San Fernando de Madrid, especialmente en su actitud corporal, composición gestual y dinámica de los brazos y, en menor medida, en la disposición de las piernas. También, alguna de estas características, se pueden encontrar en el lienzo de Veronés, existente en el Westminster Hospital, de Londres ${ }^{18}$. De idéntica manera, mirada hacia 10 alto, esquema posicional del cuerpo, y exclusiva presencia de ángeles a sus pies, pueden encontrarse en la obra de Strozzi, de colección particular genovesa. La cabeza, por su parte, remite una vez más al arte de Niño de Guevara, en especial, de nuevo, a la Ascensión de la S.l. Catedral.

La concepción general de la figura puede derivar, sin embargo, de algún grabado de la época, como el realizado en el año 1722 por $F$. de Grado, con el que coincide, en gran parte, en la disposición general de cuerpo, extremidades, manto y pequeña cinta con el lema, aunque el entorno figurativo en el que sitúa, la tipología del estandarte, las proporciones de la figura y la mirada, son ligeramente diferentes ${ }^{19}$.

No es descartable que algunas de estas características derivasen de grabados, como los de Jan Sadeler, Raphael Sadeler, Martino Rota, sobre obra de Zuccaro, Cornelio Cort, o F. de Grado, este último realizado en 1722, como insignia para la Orden de Clérigos Regulares Menores.

Destaca la simplicidad con que se ha resuelto el tema, limitándose a la presentación exclusiva de Cristo y de los angelitos, sin ningún otra figura. La intensa luminosidad del dorado celeste, definido en forma romboidal, limitado en los cuatro ángulos por grisáceas nubes contrasta con la oscuridad que rodea las piedras y la base donde sólo los destellos celestes crean efectos volumétricos. Precisamente la forma romboidal que muestra el fondo luminoso en que se sitúa la imagen del Resucitado, y la gran dimensión de la banderola blanca, muestran una evidente semejanza con la obra de Rizzi, del Museo de Columbia.

En el tramo correspondiente a la cúpula elíptica, se representan, en las pechinas: San Rafael, San Miguel, San Gabriel y el Angel de la Guarda.

\footnotetext{
18 N. Catálogo 262. Pignati, Teresio y Pedrocco, Filippo. Veronese. Catalogue complet, París, 1992.

19 Reproducido en Jiménez Prieco, María Teresa. Op. cit., Madrid, 1991, págs. 201.
} 
El conjunto corresponde a la ampliación de los tres ángeles individualizados y aceptados, en su representación, por la Iglesia, al que se asocia el Ángel de la Guarda, cuya devoción fue extendida en el seiscientos, por Clemente $\mathrm{X}$, a toda la iglesia ${ }^{20}$.

Especial difusión adquiere el celeste compañero ${ }^{21}$, al que es especialmente favorable la Compañía de Jesús y que tiene su origen en las representaciones de S. Rafael y Tobías.

San Miguel (Fig. 6), aparece representado de cuerpo entero, visto de tres cuartos hacia la izquierda, con lanza, escudo en el que se leen las letras capitales romanas Q.U.D. (Su lema personal: "¿Quién como Dios?») ${ }^{22}$ e indumentaria militar romana, que facilita la asociación entre héroe religioso y profano, en la que destaca el manto dorado ${ }^{23}$, desplegado en zig-zag. En la mano derecha, porta una espada y, sin mostrar esfuerzo ni fatiga, con un rostro sereno, como lo definió Reni en su obra de los Capuchinos de Roma, arremete contra el demonio postrado y derrotado a sus pies en violento escorzo representado como indica Palomino, "en figura humana de hombre desnudo, feo, abominable y oscuro, con luengas orejas, cuernos, uñas de águila y cola de serpiente» ${ }^{24}$. Este aspecto no deja de ser clave explicativa de la propia perfección del Arcángel, como expone el Padre Nieremberg, cuando afirma "Todo esto que fue Luzbel es ahora San Miguel(...)traspassandose a él, por sus grandes merecimientos la hermosura sobrenatural y prerrogativas de Luzbel ${ }^{25}$ "

20 Un conjunto de estas mismas advocaciones se puede encontrar en la capilla de los Mártires de la iglesia de San Pedro, en Córdoba, obras de Duque Cornejo. Díaz Vaquero, María Dolores. "Tipologías iconográficas de las jerarquías angélicas en la escultura barroca: el ejemplo cordobés", Cuadernos de Arte e lconografía, tomo II, n. ${ }^{\circ}$ 3, Madrid, 1989, págs. 265-273.

21 MÂLE, Emile. L'art religieux de la fin de XVI s. du XVII s. et du XvIII s. Etude sur l'iconographie apres le Concile de Trente, Paris, 1956, págs. 301-309.

22 Esta traducción literal es interpretable como «Quién es como Dios», o «El que es como Dios», pero el padre Nieremberg, afirmando la humildad del Arcángel, reconocedor de que no hay cosa comparable a Dios, indica, como interpretación más correcta de su nombre "¿Quién con Dios?». NIEREMBERG, Eusebio. Devoción y patrocinio del patrón de la iglesia y de los dominios de España, el glorioso Arcángel San Miguel, Madrid, 1747, pág. 13.

${ }_{23}$ Las piedras preciosas y el oro también son considerados como resúmenes de los atributos de los ángeles, asociándose las nueve piedras preciosas a los nueve coros de ángeles, afirmando el padre Nieremberg «..finalmente el oro es toda su obra por cuanto ay en este precioso espíritu es precioso y raro". Ibidem, pág. 31.

El mismo procedimiento de asociación de virtudes, o dones naturales, y joyas, realiza el padre Fray Feliciano de Sevilla. SevILLA, Fray Feliciano. Los Angeles Principes del Empyreo, quantos y quales sean sus excelencias, quantos y quales los beneficios que nos haces, a que personas se esmeran en asistir $y$ favorecer, mas de que manera los obsequiaremos y obligaremos mucho, Sevilla, 1717, pág. 58.

24 Palomino, Antonio. El Museo Pictórico y escala óptica (Madrid, 1715-1724), Madrid, 1988, pág. 206.

25 Nieremberg, Juan Eusebio. Op. cit., pág. 30. 


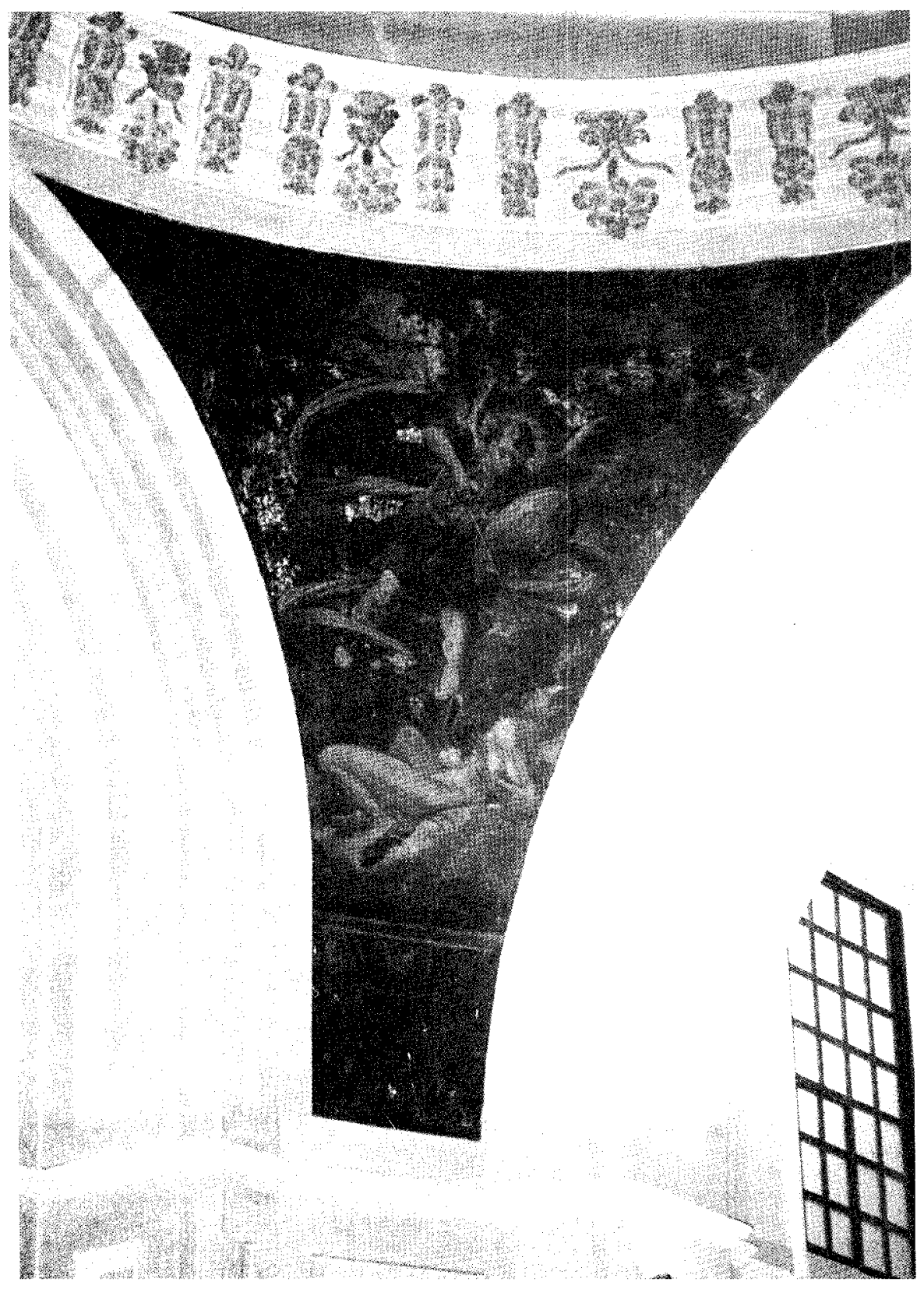

Fig. 6. San Miguel Arcángel. Iglesia de la Concepción 
Como señala Villete, la lucha no se encuentra aludida, precisamente para hacer extremadamente patente la oposición victoria/derrota ${ }^{25}$ en aquél que reúne la perfección de los nueve coros angélicos, representados en las nueve piedras preciosas, y que vio, según la piedad popular ${ }^{27}$, su triunfo asociado a la aceptación y defensa de la Inmaculada, ya que, al aceptar esta decisión de Dios se vieron armados, con ella, en su pelea con los malos ángeles. De esta manera su carácter militante se asocia a la defensa de la definición dogmática de la Inmaculada, exaltándose el valor de la propia imagen de la Concepción como arma eficaz contra el demonio y la herejía ${ }^{28}$.

Obra de interesante dibujo, su dinámica composición parte, como es habitual en España, de soluciones rafaelescas definiendo un esquema de «diagonales encontradas». La figura, que yace en el suelo ocupando el vértice inferior de las correspondientes pechinas, se dispone, al igual que sucede en la representación de San Rafael, dibujando una masa diagonal de gran dinamismo, acorde con la posición de los Arcángeles, reclinados en diagonal hacia adeiante y con las alas extendidas en una composición extraordinariamente barroca. Se rellena el resto de la pechina con motivos decorativos arquitectónicos: gran capitel compuesto en la parte inferior y friso con decoración de zapatas y molduras en la parte superior.

La relación más directa y cercana de esta obra, independientemente de la vinculación que pueda establecerse respecto a las obras de Rafael y Reni, difundidos por diversos grabados, o con el grabado de García Hidalgo, posiblemente inspirado en el cuadro de Zurbarán de la Parroquia de Zafra, se establece, según Clavijo ${ }^{29}$, con la obra del mismo existente en la Catedral de Málaga, de mano de Niño de Guevara (Fig. 7). Con ellas coincide en su concepción formal y se diferencia fundamentalmente en la figura del demonio.

Además, el rostro del arcángel, muestra evidentes similitudes con el Arcángel San Gabriel, de la Anunciación, de la capilla del Sagrario, en la

\footnotetext{
26 VILLETE, Jeanne. L'ange dans l'art d'occident de XIfeme au XV/eme siecle, París, 1940, pág. 193.

27 Este planteamiento fue popularizado, especialmente, por Sor María de Agreda. AGREDA, Sor María de. Mystica ciudad de Dios, milagro de su omnipotencia y abismo de la gracia. Historia divina de la virgen Madre de Dios, Reina y Señora nuestra María Santísima, restauradora de la culpa de Eva y medianera de la Gracia, Madrid, 1670, pág. 73.

28 Rave Prieto, Luis. "Dos obras de la escuela de Murillo en Marchena. Notas sobre la iconografía de los arcángeles en la pintura sevillana", Archivo Hispalense, tomo XV, n. ${ }^{\circ} 48-49$, Sevilla, 1951, págs. 130-135.

29 ClaviJo, Agustín. Op. cit, pág. 1.065.
} 


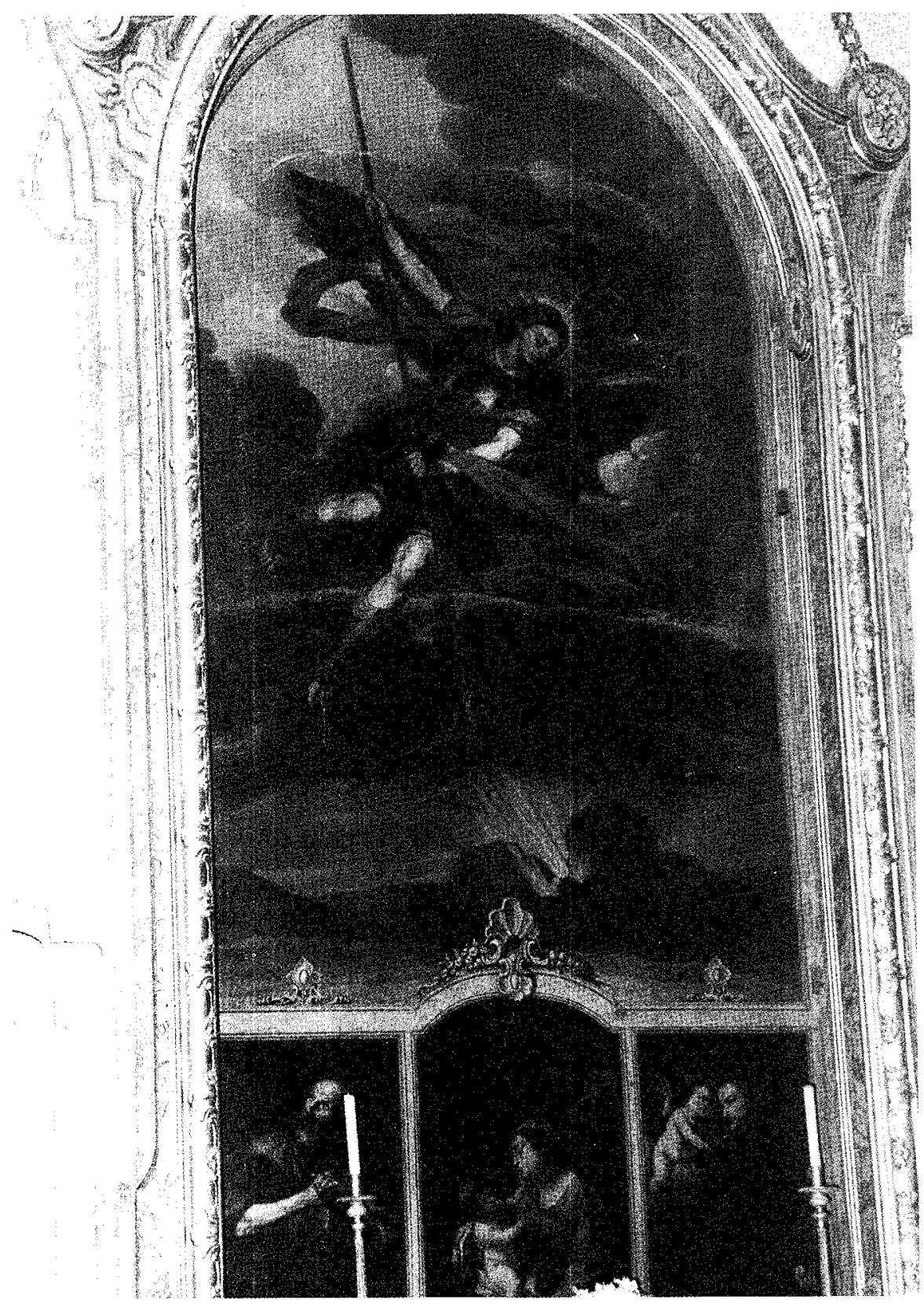

Fig. 7. San Miguel Arcángel. Niño de Guevara. Catedral de Málaga 
Iglesia de San Pedro, y el diseño en amplia espiral de la capa, junto a la posición del ángel caído, muestran semejanzas con la disposición de obras como la de Navarrete, o Fray Vicente de Santo Domingo, de la Parroquial de Briones, en la Rioja.

San Rafael (Fig. 9), quizás la representación más original del conjunto, es representado en el momento en que, según el libro de Tobías $(6,1-6)$, el joven:

"habiéndose parado en la primera posada junto al río Tigris, acompañado del ángel y de su perro, salió para lavarse los pies, y he aqui que saltó un pez disforme para tragárselo. A cuya vista Tobias, despavorido, dio un gran grito, diciendo: / Señor que me embiste Dijole el Ángel: Agárrale de las agallas y tíralo hacia ti; lo que habiendo ejecutado, lo arrastró a la tierra y empezó el pez a palpitar a sus pies. Díjole entonces el ángel: desentraña este pez, y guarda su corazón, la hiel y el hígado, pues estas cosas son útiles medicinas para la salud del cuerpo"

Aparece, el arcángel, en diagonal hacia la derecha, con la mirada dirigida hacia abajo, donde se encuentra el joven, sentado junto al río con su perro. El primero viste túnica blanca-grisácea de movidos pliegues. El segundo, con su pie derecho desnudo en escorzo, viste túnica roja y camisón blanco. Las manos del primero y la mirada del segundo marcan uno de los ejes diagonales cruzados de una composición dinámica.

En cierta medida, por la solución dada al movimiento de su manto, y por la posición que adopta el arcángel, pueden vislumbrase algunas similitudes entre su imagen y la que pintó Palomino en su Aparición del arcángel san Rafael al Venerable Andrés de Roelas, situado en la capilla de Santa Teresa, de la Mezquita Catedral, de Córdoba.

Por su parte, en el lado correspondiente al muro del evangelio encontramos en la pechina más alejada del altar, frente a San Rafael, el Ángel de la Guarda ${ }^{30}$ (Fig. 8), tema, que puede ser considerado el resultado de la representación ideal de San Rafael guiando a Tobías, pero presentando a un niño indefenso de corta edad.

30 El proceso de identificación e integración de la humanidad en la jerarquía celeste, que supone el desarrollo del culto a los dos niveles inferiores de ella lleva, poco a poco, según afirma Christine Poletto, a un fenómeno de precisa identificación entre el sujeto y un personal doble alado (arcángel en el caso de los reyes), protector exclusivo que sólo velará por él. Su culto nace, según la autora, en Rodez, a principios del siglo xvI, donde Bx. François D'Estang hizo componer el oficio de ángeles guardianes, aprobado por León X. Tuvo lugar, su primera misa, en Rodez, el tres de junio de 1526. Poletto, Christine. Art ef pouvoirs a l'age baroque. Crise mystique et crise esthetique aux Xvie et Xvile siecles, París, 1990., pág. 52-55. 


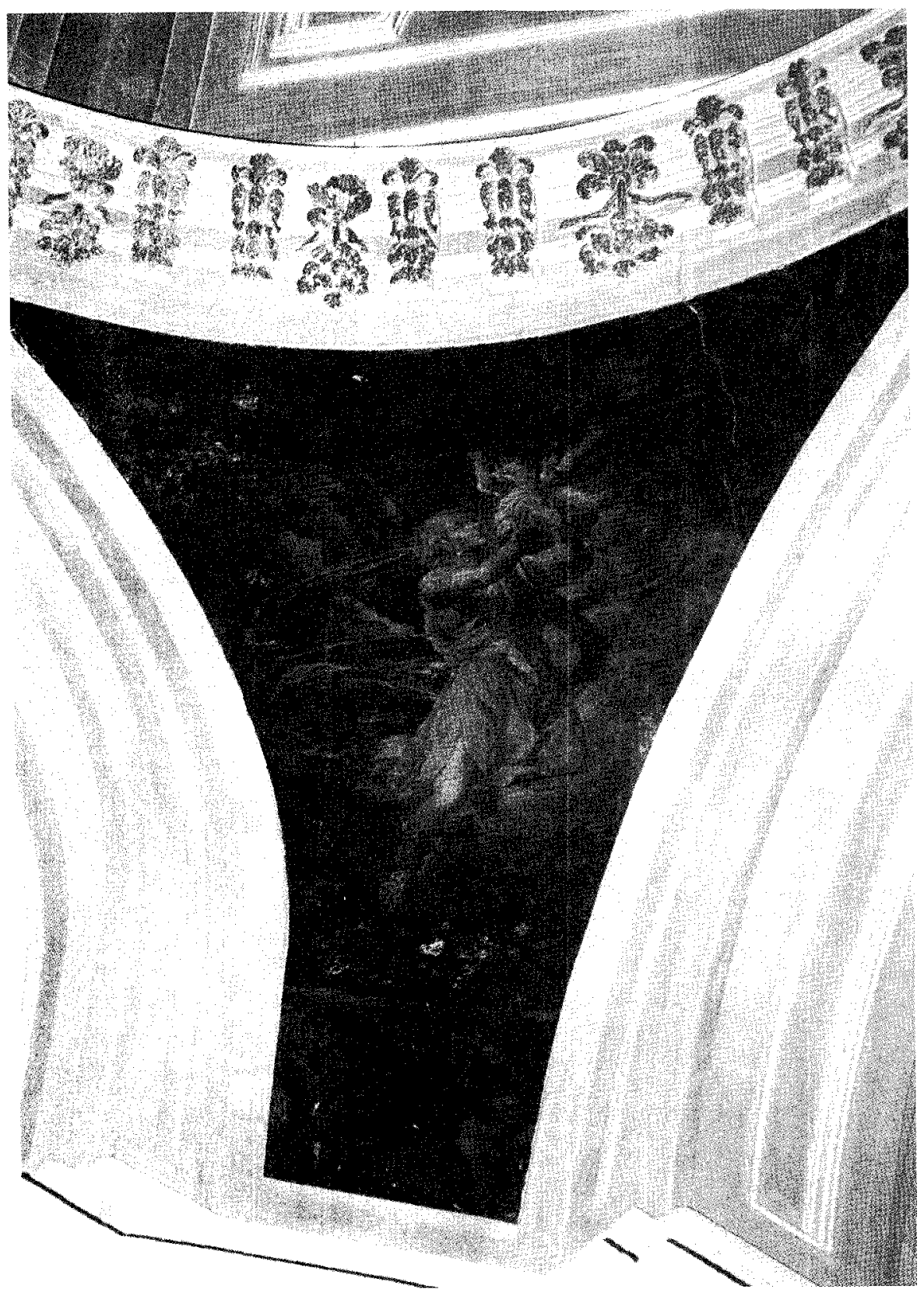

Fig. 8. Iglesia de la Inmaculada Concepción. Ángel de la Guarda. 
Programa pictórico de la lglesia de la Inmaculada del antiguo colegio de Clérigos...

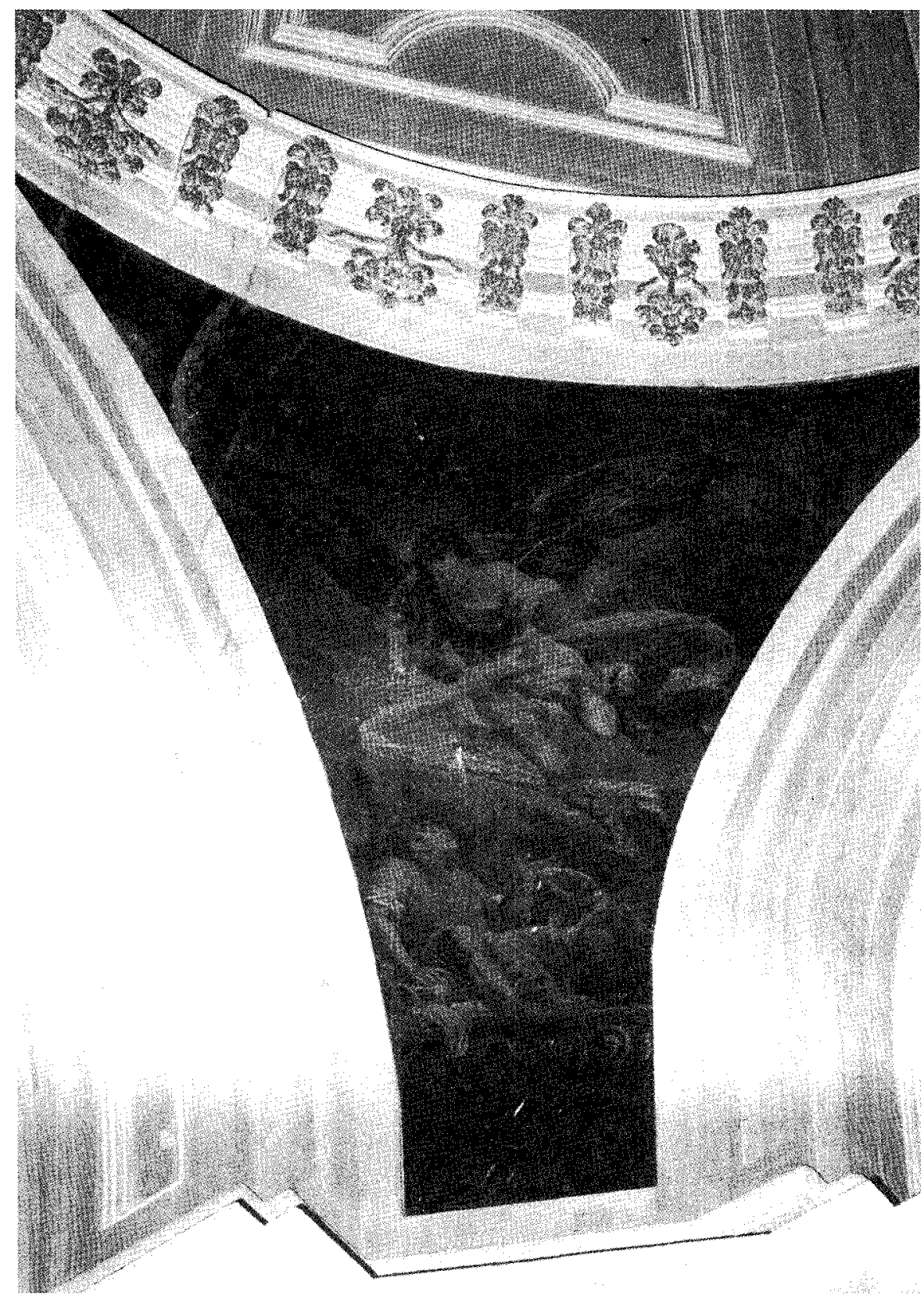

Fig. 9. San Rafael Arcángel. Iglesia de la Concepción. 
Aunque la idea del ángel guardián o custodio aparece en el Salmo 91(90v), 10-12 («No te alcanzará la desgracia,/ ni la plaga rondará tu tienda,/ porque ha ordenado a sus ángeles/ que te protejan en todos los caminos") y en los sermones de San Bernardo, abad, se glosa su figura y la devoción que se les debe ${ }^{31}$, fue defendido especialmente por el obispo de Rodez ${ }^{32} y$, al parecer, lo encontramos, por primera vez en la obra de Francisco Gonzaga De origine Seraphicae Religionis Franciscanae euiusqui progesibus de Regularis Observanciae institunionem, forma, administrationibus ac legibus admirabilique eius pepagatione, publicada en Roma en 1587.

En la parte correspondiente al patronzago de la Provincia del Santo Angel se observa la leyenda "San Rafael» en una cartela y una imagen muy parecida. En ella, un niño, con los símbolos de la copa y el pez, relacionados con la curación de la vista, se asocia a la figura del arcángel como guía de la espiritualidad. Esta obra parece ser que fue bien conocida por los pintores del XVII y pudo servir a alguno de ellos, como parece acreditar el Angel de la Guardia de Murillo existente en los Capuchinos de Cádiz ${ }^{33}$.Con rostro varonil, imberbe, y cabello rubio y acaracolado, camina con un niño vestido del blanco traje de la pureza, sobre su hombro. Con sus alas extendidas, lo levanta en actitud de ofrecerlo al cielo, en el punto de emanación de la luz que ilumina la obra. Enlaza, esta manera de representar el tema, con las representaciones de San Cristóbal, quizás por las exigencias que el espacio imponía para la composición y articulación de las figuras.

La robusta figura del Ángel, no sigue su iconografía de delicada hermosura. El niño, representado con los brazos abiertos sin ningún tipo de rigidez ni frialdad es de un realismo concreto que hace pensar en la utilización de un modelo directo, que, según Clavijo ${ }^{34}$, le emparenta con los ejecutados por Pedro de Mena, concretamente con el que aparece en el San Antonio de Padua, del Coro de la Catedral ${ }^{35}$.

Frente a él, se encuentra San Gabriel (Fig. 10) cuyo nombre significa «poderío de Dios» ${ }^{36}$. Aparece en una postura más vertical, equilibrada

$3 t$ Sermón 12, sobre el salmo "Qui habitat". SAn BERnARDo, Opera omnia, Madrid, 1966, págs. 458-462.

32 REAU, Louis. Iconographie de l'Art chretienne, París, 1956-1958., t. Il, págs. 33 y 53.

33 Castillo, M. ${ }^{\text {a }}$ José. "Posibles influencias de una crónica franciscana en la temática de Murillo", Archivo Hispalense, 2. Época, tomo XV, n. ${ }^{\circ} 48$, Sevilla, 1951, págs. 31-36.

${ }^{34}$ Clavijo, Agustín. Op. cit., Barcelona, 1993, pág. 1.069.

35 Ibídem., pág. 1.069.

36 Ya que es el enviado cuando el poder y la omnipotencia de Dios se ponen de manifiesto. SÁNCHEZ ESTEBAN, Natividad. "Sobre los Arcángeles», Cuadernos de arte e iconografía, tomo IV, n. ${ }^{\circ} 8$, Madrid, 1991, 91-101. 
Programa pictórico de la Iglesia de la Inmaculada del antiguo colegio de Clériços...

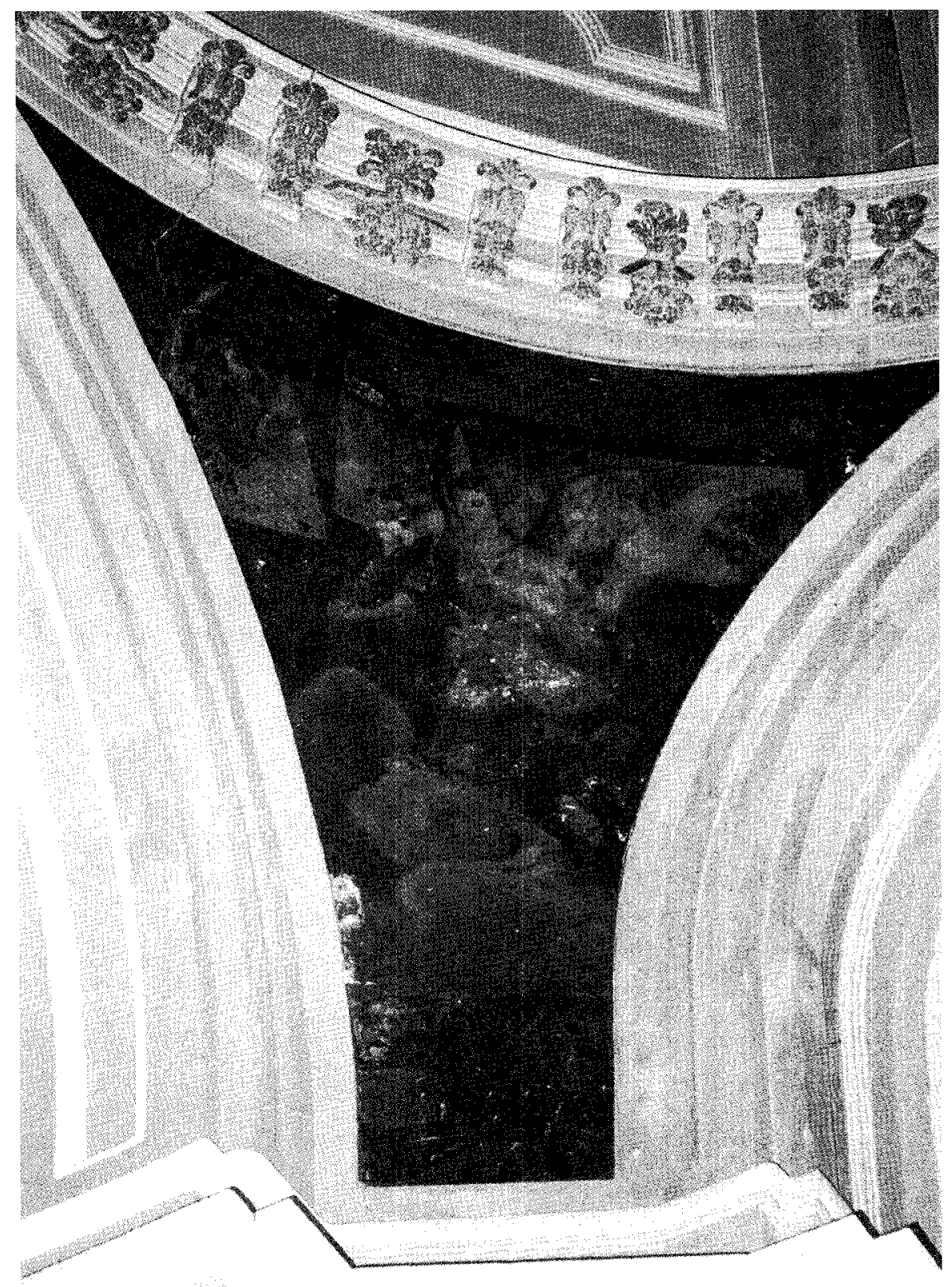

Fig. 10. San Gabriel. Iglesia de la Inmaculada Concepción. 
y armoniosa, sobre nubes, con rostro juvenil, imberbe y cabello rubio acaracolado. Viste túnica azul y manto rojo, portando las azucenas blancas, su atributo personal, en la mano izquierda. Para el profesor Clavijo, es el menos logrado de los cuatro, por sus defectos de dibujo y escasa inventiva de composición, lo que le hace pensar en unos desafortunados retoques restauradores, o en la intervención de una mano distinta ${ }^{37}$.

En la cabecera de la iglesia, sobre el altar, se sitúa la escena de la Coronación de la Virgen (Fig. 11). Se representa un tema que, en cierta medida, supone, para la pintura barroca, un reencuentro con la Leyenda Dorada y la fe en la Asunción, a la que no añade valores propiamente nuevos. En ella se elige el momento de su traslado a los cielos en cuerpo y alma, y de recepción de la corona, símbolo de su peculiar unión con Dios.

Ocupa la figura de la Virgen, con túnica blanca y manto azul, el centro de una composición en aspa, mientras que, a los pies, al igual que sucede con el Resucitado, aparecen infantiles ángeles. Sobre ella, se forma un triángulo compositivo sobrepuesto al definido por un resplandor dorado, y paralelo al formado por ángeles y nubes, integrado por el Padre, todo de blanco, Espíritu Santo y el Hijo con un gran manto rojo. Se representa, pues, la escena de la glorificación, con toda la Corte Celestial, viniendo al encuentro de María, como lo comenzó a representar Corregio, y a la Trinidad efectuando la coionación de María, como se hizo común desde $1400{ }^{38}$.

María, según Clavijo ${ }^{39}$, guarda gran semejanza con las de Niño de Guevara, por sus ojos grandes, nariz pronunciada, boca de labios gruesos y cuello ancho. Parece, sin embargo, por sus proporciones, encontrarse más cercana a la imagen representada por Cano en la Catedral de Granada.

En la figura del Padre Eterno, se siguen las indicaciones de Pacheco y, en la de Cristo, según el mismo autor, encontramos importante simi-

37 Clavijo, Agustín. Op. cit., Barcelona, 1993, pág. 1.068.

38 Se presenta, así, el triunfo de Maria a través de su coronación, en el momento en que el Padre Eterno va a colocar sobre la cabeza de la Virgen una corona real, que sostiene en su mano derecha, mientras que al otro lado Jesucristo le ofrece un cetro. La Virgen, en el centro, aparece de rodillas sobre nubes querubines y ángeles, mirando, recatada y emocionada, al cielo, respondiendo, en sus proporciones y posición al modelo definido por Rubens y divulgado por grabados, como el citado con anterioridad. Peculiares son, sin embargo, los ángeles que le rodean, a sus pies, especialmente los dos mancebos, de complejo y contrapuesto escorzo que se sitúan a su derecha e izquierda. De ellos, el segundo muestra una clara semejanza con el que Cano sitúa en su Asunción, de la Catedral de Granada.

39 Clavijo, Agustín. Op. cit., Barcelona, 1993, pág. 1.064. 
Programa pictórico de la Iglesia de la Inmaculada del antiguo colegio de Clérigos...
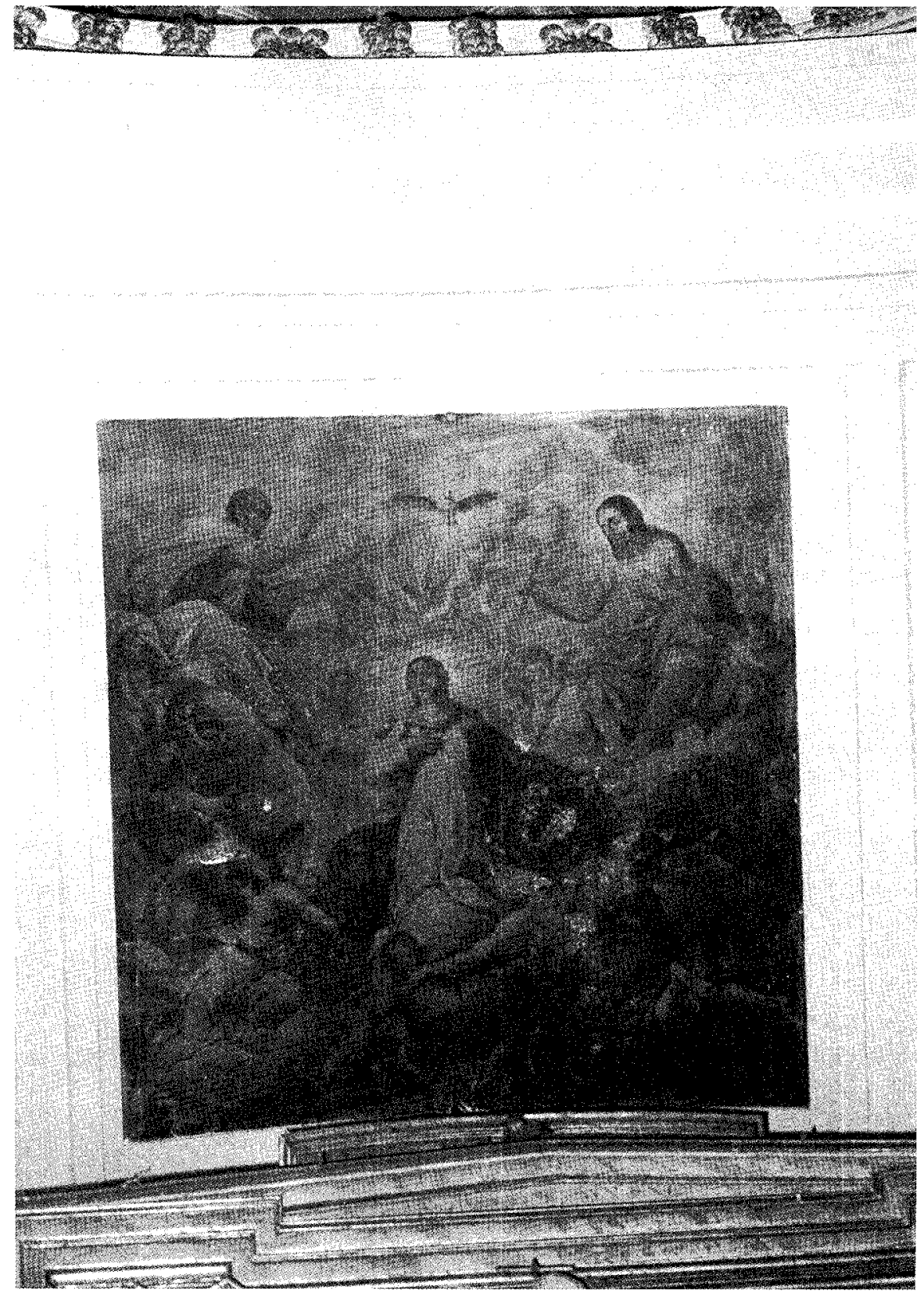

Fig. 11. Coronación de la Virgen. Iglesia de la Concepción. 
litud con las que aparecen en la Duda de Santo Tomás, del Hospital de Santo Tomas, y con el Salvador, de la Iglesia del Sagrario. Ambas se sitúan en posiciones invertidas, respecto a lo que solía ser habitual en este tipo de obras: Dios Padre a la derecha de María y Cristo a su izquierda, como se representa en un dibujo atribuido a Pacheco o Juan de Noort. Además, el conjunto muestra un dinamismo que es extraño encontrar en otras obras de semejante tema, especialmente intensificado en la figura de Dios Padre. El Hijo, en posición de tres cuartos presenta una posición más tradicional, encontrándose representado, como era preceptivo, según Pacheco ${ }^{40}$, sólo con el manto, como Resucitado.

En esta obra, destaca el atractivo de ángeles y querubines, emparentados con los del ciclo del Hospital de Santo Tomás. Sería este un detalle que indicaría una realización posterior a las anteriores obras.

Según el profesor Clavijo ${ }^{41}$, la obra, en su conjunto, muestra la huella de Niño de Guevara, en este caso en la concreta concepción de la Virgen, cercana a la Asunción de la Catedral de Málaga (Fig. 12) en tipología, concepto de masas y monumentalidad, que recuerdan el mundo flamenco. Ambas tendrían su antecedente común en la Asunción de la Catedral de Granada, de Alonso Cano. Parece, sin embargo, que la dependencia puede ser más directa, respecto al ejemplar granadino, tanto por la concepción general de las proporciones, como por la presencia de los ángeles mancebos, aunque no hay que olvidar que la figura de María puede enlazar con modelos grabados, como el citado, y el realizado por Lorenzini, a partir de una obra de Guido Reni, siempre, en lo referido al primer nivel de la representación.

Este grabado nos muestra a María con un halo luminoso, que puede ser la base que hace posible la concreción de una original idea: su coronación, por los ángeles, con una corona de estrellas. Esto, unido a la utilización de túnica blanca y manto azul, permite una caracterización más inmaculadista y una simbiosis con el tema de la Coronación por Ángeles, como es representada en diversas obras (la grabada por Lorenzo Vaccari, por ejemplo), a través de un tipo de solución que podemos contemplar en diversas obras de $\mathrm{El}$ Greco, en las que un círculo de querubines coronan a la Virgen, rodeando el nimbo luminoso que rodea su cabeza. Precisamente, en la Asunción del Museo de Santa Cruz, de Toledo, este

40 PaCheCO, Francisco. Op. cit., pág. 658

41 Clavijo, Agustín. Op. cit, pág. 1.025. 


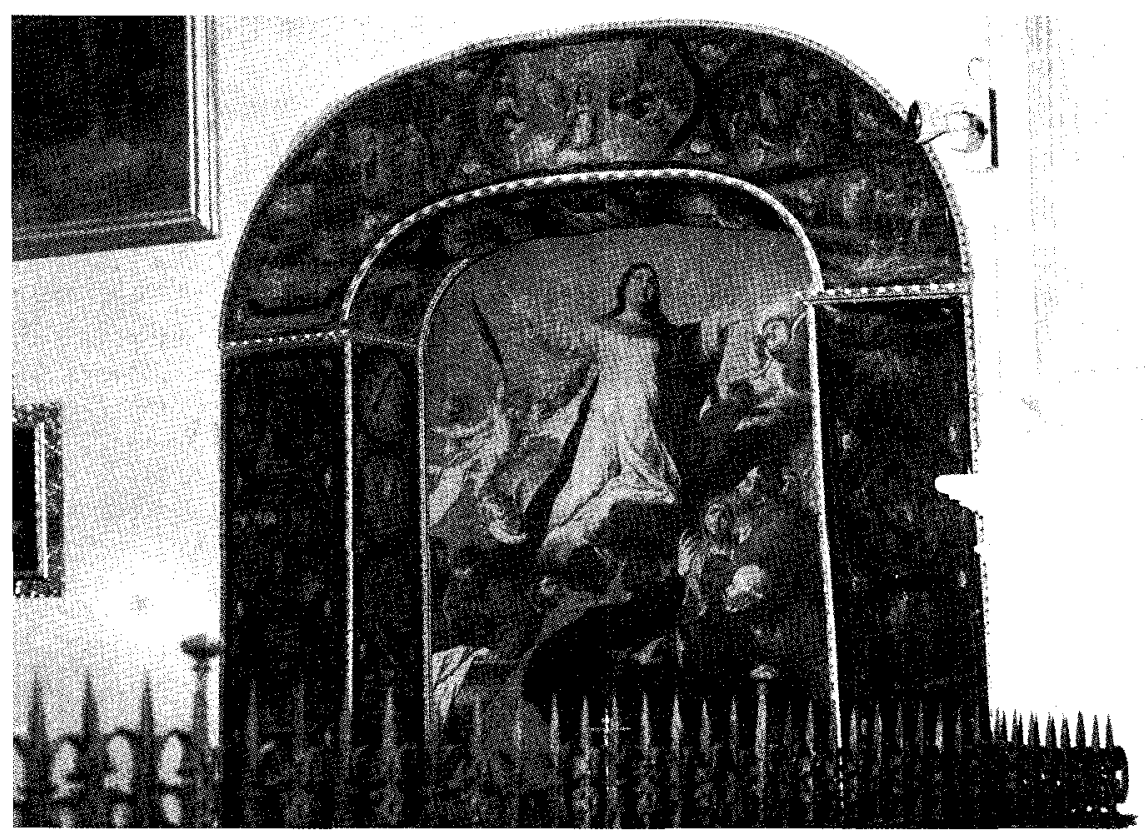

Fig. 12. Asunción de la Virgen. Juan Niño de Guevara. Catedral de Málaga.

elemento aparece junto a dos ángeles mancebos, a sus pies, en posiciones escorzadas.

En el conjunto iconográfico, destaca la asociación establecida entre la fundación de la orden y la Iglesia Triunfante representada en las escenas de Resurrección y Asunción. No en vano, como ya se ha señalado, Adorno y Caracciolo profesaron el día de Pascua de Resurrección. Pero, además, la presencia de los arcángeles nos muestra, también, la importancia de la acción militante, de la defensa de los dogmas y en especial los cuestionados por el protestantismo, referidos tanto a la Virgen María como a la propia autoridad del Pontífice.

Temboury, en sus notas, señala que estas solemnes obras, en las que nadie ha reparado, son espléndidas, siendo la que está sobre el coro de composición barroquísima, digna de Rubens, con muchas figuras y arquitecturas, mientras el Resucitado es de composición más simple y mucho más claro de entonación ${ }^{42}$.

42 A. T. Nota citada. 
Por su parte, Clavijo, las consideraba parte de un conjunto que en su día debió de ser mucho más amplio, todo él obra de Diego de la Cerda, que mostraría su preparación y valentía para enfrentarse a una técnica nueva en la ciudad. Formalmente, como se ha ido exponiendo anteriormente, ve en ellas claros antecedentes en la obra de Niño de Guevara y resonancias sevillanas del mundo murillesco ${ }^{43}$.

La presencia de otros conjuntos pictóricos realizados en la misma época y con idéntica técnica (Cripta de San Lázaro, Capilla del Sagrario de la parroquía de San Pedro del Perchel), junto con la aparición de pintores relacionables con algunos de ellos, como Pedro de Hermosilla ${ }^{44}$, amplían el posible campo de atribución del conjunto.

43 Clavijo, Agustín. Op. cit., Barcelona, 1993, pág. 998.

44 González SegarRa, Sebastián. PIntura y pintores en Málaga durante el reinado de Felipe $V$, tesis doctoral en microfichas, UNED, Barcelona, 1999, págs. 997-1.017. 